\title{
Pentingnya Pendidikan Agama Kristen Di Sekolah Mengantisipasi Kecanduan Smartphone Bagi Anak Kelas 6 Di Sekolah Dasar Theodore Batam
}

\author{
Alfian, ${ }^{1 *}$,Dewi Lidya $S,{ }^{2}$ Benteng Martua Mahuraja Purba,${ }^{3}$ Hendri Hutapea ${ }^{4}$ \\ Prodi PAK, STT Real Batam \\ Prodi PAK, STT Real Batam \\ Prodi PAK, STT Real Batam \\ Prodi PAK, STT Real Batam \\ pncdwilestari@gmail.com
}

\begin{abstract}
The development of the times was followed by technological developments as well as the consumptive behavior of electronic devices such as smartphones. This technological progress has two impacts, namely positive and negative impacts. The positive impact is that humans get ease in accessing information, connecting with others quickly through social networks. The negative impact of smartphone usage on elementary school children is excessive use, plus there is no healthy control mechanism both at school and at home. The purpose of this paper is to focus on relevant Christian religious education without having to reject the progress of the times for students so that the problem of smartphone addiction can be anticipated early on. This research uses descriptive method and case study with a qualitative approach.
\end{abstract}

Keywords: Education, Christianity, anticipating, addicted, Smartphone

\begin{abstract}
Abstrak
Perkembangan zaman disusul dengan perkembangan teknologi serta perilaku komsumtif akan alatalat elktronik seperti smartphone. Kemajuan teknologi ini membawa dua dampak, yaitu dampak positif dan dampak negatif. Dampak positifnya ialah manusia mendapatkan kemudahan di dalam mengakses informasi, terhubung dengan orang lain dengan cepat melalui jejaring sosial. Dampak negatif dari pemakaian smartphone pada anak SD adalah pemakaian yang berlebihan, ditambah tidak ada mekanisme kontrol yang yang sehat baik di sekolah maupun di rumah. Tujuan dari paper ini adalah untuk memusatkan pendidikan Agama Kristen yang relevan tanpa harus menolak kemajuan zaman bagi para peserta didik sehingga masalah kecanduan smartphone dapat diantisipasi sejak dini. Penelitian ini menggunakan metode deskriptif dan studi kasus dengan pendekatan kualitatif.

Kata kunci: Pendidikan, Agama Kristen, mengantisipasi, kecanduan, Smartphone
\end{abstract}

\section{PENDAHULUAN}

Pentingnya Pendidikan Agama Kristen di sekolah oleh guru sebagai ujung tombaknya bagi usia anak kelas 6 merupakan tantangan tersendiri. Ardianto Lahagu menjelaskan keunikan pendidikan agama Kristen terletak dari corak moral Kristiani yang 
berisi tentang nilai-nilai kebenaran iman Kristen. ${ }^{1}$ Teknologi yang telah berkembang sedemikian bagus dan canggih nya yang semuanya di bangun menggunakan investasi yang tidak murah serta telah mengambil waktu yang tidak pendek dalam perkembangan nya. Kesemua nya itu tidaklah lain guna untuk mempermudah dan memberikan kenyamanan pada kehidupan manusia itu sendiri. Dari semua rencana awal dan apa yang dianggap baik dalam memberikan kemudahan serta kenyamanan telah terjadi penyimpangan, kesalahan dan kelebihan penggunaan hingga mengakibatkan banyak kasus gangguan serta kelainan perilaku para pengguna tidak dengan benar tersebut.

" Poli jiwa RSUD Dokter Koesnadi, Bondowoso sejak Desember lalu merawat dua pasien kecanduan smartphone alias smartphone. A berusia 11 tahun dan $\mathrm{H} 12$ tahun berstatus pelajar dari sebuah SD di Bondowoso. Seperti ditayangkan dalam Liputan6 Malam SCTV, Kamis (18/01/2018), hasil diagnosa kejiwaan kedua pelajar itu mengalami kecanduan tingkat akut. Mereka bisa marah besar sampai membanting-banting benda atau menyakiti diri sendiri jika diminta melepaskan smartphone dari tangannya." 2

"Seorang anak lelaki berusia 13 tahun asal Zhejiang, China, dia berperilaku seperti bayi yang tidak bisa berjalan atau berbicara atau menjaga dirinya sendiri. Bahkan setelah ia dibawa ke Departemen Neurologi dan Departemen Rheumatologi, kondisinya masih belum membaik.

Para dokter kemudian melakukan pemeriksaan terperinci terhadap bocah itu dan melihat laporan tes sebelumnya untuk menentukan apa sebenarnya yang dideritanya. Hingga mereka mendiagnosis sang bocah menderita Ensefalitis Autoimun

Dokter menjelaskan, akibat dari bermain ponsel terus-menerus hingga tengah malam dan tidak mendapatkan istirahat yang baik, sistem kekebalan tubuhnya melemah dan mengakibatkan Ensefalitis Autoimun."3

Untuk menyelesaikan masalah yang bersifat ilmiah perlu adanya hipotesa. Hipotesa dapat diartikan sebagai patokan atau dugaan sementara. ${ }^{4}$ Menurut Sutrisno Hadi "Hipotesa adalah jawaban sementara tentang suatu penelitian yang kebenaran nya akan dibuktikan dengan jalan penelitian." 5

Adanya kelainan perilaku anak didik di keluarga dan di beberapa sekolah dasar di batam akibat kecanduan smartphone atau smartphone.Bila di tinjau dengan waktu istirahat bagi anak usia sekolah dasar maka Hidayat, menjelaskan Anak usia sekolah membutuhkan

\footnotetext{
${ }^{1}$ Ardianto Lahagu, "Peran Pendidikan Agama Kristen Dalam Membangun Karakter Remaja Di Sekolah Menengah Pertama," Real Didache 2, no. 1 (2017): 105-129.

2 “Https://Www.Liputan6.Com/News/Read/3230086/Kecanduan-Smartphone-2-Pelajar-Di-BondowosoAlami-Gangguan-Jiwa," 1 Oktober 2019.

3 “Https:/Www.Suara.Com/Health/2019/07/05/063500/Kecanduan-Ponsel-Bocah-Ini-Idap-GangguanKesehatan-Mental," 1 Oktober.

${ }^{4}$ S. Wojowasito, Kamus Lengkap Inggris-Indonesia (Bandung: Hasta, 1980).

${ }^{5}$ Sutrisno Hadi, Methodology Research D (Yogyakarta: YPFP UGM, 1986).
} 
waktu setidaknya 10 jam per hari untuk tidur. ${ }^{6}$ Selain itu, pada usia 6 tahun, anak akan tidur malam rata-rata 11-12 jam, sementara anak usia 11 tahun tidur sekitar 9-10 jam . Dengan pengetahuan dasar seperti ini maka setiap saat waktu bagi anak - anak di usia sekolah dasar itu seharusnya agar dikelola dengan baik agar keseimbangan kebutuhan baik belajar, bermain dan istirahat dapat terpenuhi dengan benar dan baik. Disamping itu juga orang tua harus memastikan benar kualitas istirahat anak nya karena kebutuhan tidur bukan hanya dilihat dari berapa lama nya anak tidur tetapi juga kedalaman tidurnya ( kualitas ), dengan kualitas yang benar bukan hanya mendukung pertumbuhan anak tetapi juga perkembangan mental serta perilaku hidup baik terus terjaga yang membuat kepercayaan diri anak dapat bertumbuh kembang dengan maksimal.

\section{METODE}

Dalam penelitian ini, penulis menggunakan metode deskriptif dan studi kasus dengan pendekatan kualitatif. Penulis menggunakan metode deskriptif untuk pengumpulan data-data literatur dan dokumen-dokumen. Sedangkan metode studi kasus dipergunakan untuk mengumpulkan data-data lapangan. Penulis menggunakan pendekatan kualitatif karena penelitian ini meneliti obyek yang alamiah dimana peneliti sebagai instrumen kunci. Disamping itu, pendekatan kualitatif lebih mengutamakan pada makna. Makna yang diungkap berkaitan dengan persepsi orang mengenai suatu keadaan. Proses alamiah pun terjadi antara peneliti dengan subyek / orang yang diteliti, sehingga data yang diraih pun tidak perlu ditransformasi menjadi angka untuk menghindari hilangnya informasi yang telah diperoleh.

\section{HASIL DAN PEMBAHASAN}

\section{Deskripsi Data Wawancara}

Pada dasarnya orangtua anak Michael (Responden 1) sangat percaya bahwa melalui Pendidikan sekolah Kristen dapat membina kerohanian anak menjadi lebih baik. Begitu juga orangtuanya mendukung metode pengajaran yang diberikan dan tidak mendapati ketidaksetujuan dari apa yang telah diberikan sekolah selama ini. Respon baik orangtua juga menyatakan sangat senang apabila anak diajarkan lebih banyak kepada Firman Tuhan, begitu juga apabila anak di berikan tanggung jawab dalam menghafalkan Firman Tuhan yang dapat menjadi suatu kekuatan bagi anak tersebut. Orangtua anak Michael juga sangat mendukung dalam hal sekolah mengajari anak dengan metode melakukan kegiatan sosial melalu Pendidikan Agama Kristen begitu juga apabila dilakukan nya tugas kelompok terhadap anak-anak agar mempunyai interaksi satu dengan yang lain. Group konseling teaching merupakan salah satu dari sekian banyak metode yang dipakai dan orangtua anak Michael juga mendukung metode yang diberikan tersebut. Dari hasil wawancara

\footnotetext{
${ }^{6}$ Hidayat A. A. A., Pengantar Kebutuhan Dasar Manusia: Aplikasi Konsep Dan Proses Keperawatan, Buku 2 (Jakarta: Salemba Medika, 2009).

${ }^{7}$ Potter P. A. \& Perry A.G., "Buku Ajar Fundamental Keperawatan: Konsep, Proses Dan Praktik," Alih Bahasa Komalasari 2, no. 4 (2005): 4.
} 
menyatakan bahwa komunikasi anak dengan orangtua cukup sering, tetapi belum di dapati bagaimana kualitas komunikasi keluarga ini. Pengaruh dari Pendidikan Agama Kristen yang di rasakan orangtua bagi anak Michael selama bersekolah adalah anak dapat dirasakan mengalami ketenangan. Orangtua yang selama ini berlaku sebagai contoh hidup bagi anak di keluarga, menjadikan orangtua pedoman utama anak belajar berperilaku selama ini.

Orangtua percaya bahwa dalam sekolah Kristen anak dapat belajar lebih banyak tentang nilai-nilai ke kristenan. Sebagai orangtua yang jeli menyampaikan ketidaksetujuan nya anak-anak yang terlalu disibukan dengan tugas dari sekolah, sementara menurut orangtua pelajaran tersebut belum dipelajari, tetapi orangtua setuju dengan nilai-nilai ke kristenan yang ditanam pada anak, melalui adanya renungan Firman Tuhan, menjaga tutur kata dan pengembangan karakter. Penanaman Firman Tuhan bagi anak melalui menghafal, mendapat dukungan dari orangtua, begitu juga dengan melakukan kegiatan social ke kristenan bagi anak. Tetapi dalam melibatkan anak pada tugas kelompok orangtua anak Davinno (Responden 2) masih menyarankan agar lebih memperhatikan semua aturan dan dalam sepengetahuan orangtua dalam kegiatan kelompok tersebut. Metode konseling untuk menceritakan hal-hal yang dialami anak, sudah di terapkan orangtua pada anak di rumah sehari dalam membangun komunikasi dan kesatuan keluarga. Perkembangan Perilaku anak yang dirasakan orangtua adalah berupa disiplin dan tanggung jawab anak dan masih tetap sama orangtua tetap menjadi panutan utama bagi anak untuk bertumbuh dan berkembang.

Sebagai orangtua tentunya menginginkan anak memiliki masa depan yang baik, itulah sebabnya anak Evi (Responden 3) disekolahkan pada sekolah Kristen, dengan alasan utama nya agar anaknya dapat diajarkan nilai nilai Kristen. Yang menjadi saran dari orangtua agar dalam hal pengajaran Firman Tuhan disekolah agar seimbang. Respon baik orangtua juga menyatakan setuju apabila anak diajarkan lebih banyak kepada Firman Tuhan, begitu juga apabila anak di berikan tanggung jawab dalam menghafalkan Firman Tuhan yang dapat menjadi suatu kekuatan bagi anak tersebut. Orangtua anak Evi juga sangat mendukung dalam hal sekolah mengajari anak dengan metode melakukan kegiatan sosial melalui Pendidikan Agama Kristen begitu juga apabila dilakukan nya tugas kelompok terhadap anak-anak agar mempunyai interaksi satu dengan yang lain. Group konseling teaching merupakan salah satu dari sekian banyak metode yang dipakai dan orangtua anak Evi juga mendukung metode yang diberikan tersebut. Dari hasil wawancara menyatakan bahwa komunikasi anak dengan orangtua cukup sering. Pengaruh dari Pendidikan Agama Kristen yang di rasakan orangtua bagi anak Evi selama bersekolah adalah anak dapat bertutur kata yang sopan. Orangtua yang selama ini berlaku sebagai contoh hidup bagi anak di keluarga, belum ada mentor atau pembimbing rohani lain nya.

Kepercayaan Orangtua terhadap sekolah Kristen dalam membangun dan membentuk kerohanian anak tetap masih menjadi tolok ukur utama. Hampir semua orangtua menyampaikan ketidaksetujuannya dimana anak-anak yang terlalu dibebankan 
oleh tugas dari sekolah seperti seolah - olah dipaksakan, sementara orangtua setuju dengan cara sekolah dalam membangun nilai-nilai ke kristenan yang ditanam pada anak, melalui adanya doa dan mendengarkan Firman Tuhan pada setiap mulai kelas dipagi hari. Sedangkan penanaman Firman Tuhan bagi anak didukung orangtua yang mengerti bahwa tujuan utama pengajaran adalah bagaimana mempengaruhi ketiga hal yaitu berupa kognitif, afektif dan motorik anak. Begitu juga dukungan orangtua anak kepada sekolah yang menberikan tugas menghafal Firman Tuhan yang menanamkan pola baru bagi kehidupan anak, sama halnya juga dengan melakukan kegiatan sosial ke kristenan yang di pahami orangtua sebagai pendorong kreatifitas, imajinasi dan inovasi bagi anak. Dalam melibatkan anak pada tugas kelompok orangtua anak Luther (Responden 4) juga mendukung dengan pemahaman membangun nilai nilai kerjasama dan kebersamaan. Untuk metode konseling dalam menceritakan hal-hal yang dialami anak, orangtua anak juga menyampaikan bahwa melatih anak dalam hal bersaksi tentang keadaan baik dan buruk yang dialami anak menjadi satu kekuatan dalam Iman dan percaya diri nya. Komunikasi anak dengan keluarga yang terus di bangun dan di jaga membangun kedekatan anak dan orangtua. Perkembangan perilaku positif anak yang dirasakan orangtua adalah berupa kemandirian dan keberanian dalam menyampaikan pendapat dengan benar dirasakan sebagai perubahan anak selama bersekolah, dimana anak Luther juga memiliki mentor atau pembimbing rohani di lingkungan gerejanya.

Sebagai orangtua tentunya menginginkan anak memiliki masa depan yang baik, itulah sebabnya anak Jesse disekolahkan pada sekolah Kristen, dengan alasan utama nya agar anaknya dapat mengenal Kristus sedini mungkin. Ada hal yang menjadi masukan orangtua agar sekolah memiliki tempat ibadah sendiri. Respon baik orangtua juga menyatakan sangat senang apabila anak diajarkan lebih banyak kepada Firman Tuhan, begitu juga apabila anak di berikan tanggung jawab dalam menghafalkan Firman Tuhan yang dapat menjadi suatu kekuatan bagi anak tersebut. Orangtua anak Jesse (Responden 5) juga sangat mendukung dalam hal sekolah mengajari anak dengan metode melakukan kegiatan sosial melalui Pendidikan Agama Kristen begitu juga apabila dilakukan nya tugas kelompok terhadap anak-anak agar mempunyai interaksi satu dengan yang lain. Group konseling teaching merupakan salah satu dari sekian banyak metode yang dipakai dan orangtua anak Jesse juga mendukung metode yang diberikan tersebut. Dari hasil wawancara menyatakan bahwa komunikasi anak dengan orangtua cukup sering. Pengaruh dari Pendidikan Agama Kristen yang di rasakan orangtua bagi anak Jesse selama bersekolah adalah anak dapat lebih mengerti saat membaca Firman Tuhan. Orangtua yang selama ini berlaku sebagai contoh hidup bagi anak di keluarga, menjadikan orangtua pedoman utama anak belajar berperilaku selama ini.

Dengan menyekolahkan anak disekolah Kristen orangtua berharap agar pengetahuan agama anak lebih dalam dan kedisiplinan bertambah. Sebagai orangtua menyampaikan bahwa apabila dalam hal hal masih wajar semua kebijaksanaan sekolah 
maka orangtua pun tidak mempermasalahkan hal iut dan melihat semua nya masih dalam koridor kurikulum yang benar. Orangtua sangat setuju dengan nilai-nilai ke kristenan yang ditanam pada anak, melalui adanya renungan Firman Tuhan, begitu juga dengan Penanaman Firman Tuhan bagi anak melalui menghafal. Dalam hal melakukan kegiatan social ke kristenan bagi anak orangtua mendukung, tetapi dalam melibatkan anak pada tugas kelompok orangtua anak Sergio Sitinjak (Responden 6) menyarankan agar lebih adanya pengawasan dan menyarankan alangkah lebih baik apabila tugas kelompok dilakukan di lingkungan sekolah. Metode konseling untuk menceritakan hal-hal yang dialami anak, lenbih menyarankan agar tidak ada unsur paksaan dan dalam batas sewajarnya. Perkembangan Perilaku anak yang dirasakan orangtua adalah berupa mandiri dan lebih bersemangat dan masih tetap sama orangtua tetap menjadi panutan utama atau contoh hidup bagi anak untuk bertumbuh dan berkembang.

Keputusan yang diambil orangtua anak Alvaro (Responden 7) bahwa melalui Pendidikan sekolah Kristen dapat membina kerohanian anak menjadi lebih baik. Begitu juga orangtuanya mendukung metode pengajaran yang diberikan dan tidak mendapati ketidaksetujuan dari apa yang telah diberikan sekolah selama ini. Respon baik orangtua juga menyatakan sangat senang apabila anak diajarkan lebih banyak kepada Firman Tuhan, begitu juga apabila anak di berikan tanggung jawab dalam menghafalkan Firman Tuhan. Orangtua anak Alvaro juga sangat mendukung dalam hal sekolah mengajari anak dengan metode melakukan kegiatan sosial melalu Pendidikan Agama Kristen begitu juga apabila dilakukannya tugas kelompok terhadap anak-anak agar mempunyai interaksi mempraktekan kasih satu dengan yang lain. Group konseling teaching merupakan salah satu dari sekian banyak metode yang dipakai dan orangtua anak Alvaro juga mendukung metode yang diberikan tersebut. Dari hasil wawancara menyatakan bahwa komunikasi anak dengan orangtua cukup sering, tetapi belum di dapati bagaimana kualitas komunikasi keluarga ini. Pengaruh dari Pendidikan Agama Kristen yang di rasakan orangtua bagi anak Alvaro selama bersekolah adalah nilai niali kebaikan akan sopan santun anak dapat dirasakan mengalami peningkatan. Orangtua yang selama ini berlaku sebagai contoh hidup bagi anak di keluarga, menjadikan orangtua pedoman utama anak belajar berperilaku selama ini.

Kepercayaan Orangtua terhadap sekolah Kristen dalam membangun dan membentuk kerohanian anak tetap masih menjadi tolok ukur utama. Orangtua menyampaikan sarannya agar pengajaran tidak terlalu kaku dimana anak-anak lebih diberikan kelonggaran supaya dapat nyaman dalam proses belajar mengajar. Sementara orangtua setuju dengan cara sekolah dalam membangun nilai-nilai ke kristenan yang ditanam pada anak, melalui adanya doa dan mendengarkan Firman Tuhan pada setiap mulai kelas dipagi hari. Sedangkan penanaman Firman Tuhan bagi anak didukung orangtua yang mengerti bahwa tujuan utama pengajaran adalah bagaimana mempengaruhi ketiga hal yaitu berupa kognitif, afektif dan motorik anak. Begitu juga dukungan orangtua anak 
kepada sekolah yang menberikan tugas menghafal Firman Tuhan yang menanamkan pola baru bagi kehidupan anak, sama halnya juga dengan melakukan kegiatan sosial ke kristenan di dukung oleh orangtua. Dalam melibatkan anak pada tugas kelompok orangtua anak Sean (Responden 8) juga mendukung dengan pemahaman membangun nilai nilai sosial serta kerjasama. Untuk metode konseling dalam menceritakan hal-hal yang dialami anak, orangtua anak juga menyampaikan bahwa melatih anak dalam hal bersaksi tentang keadaan baik dan buruk yang dialami anak menjadi satu kekuatan dalam Iman dan percaya diri nya. Komunikasi anak dengan keluarga yang terus di bangun oleh orangtua dengan pertanyaan pertanyaan yang mendetail sekaligus untuk memeriksa tuga rutin yang diberikan sekolah kepada anak. Perkembangan perilaku positif anak yang dirasakan orangtua adalah berupa bertanggung jawab, walaupun dirasakan masih belum cukup, tetapi secara keseluruhan sudah baik sebagai perubahan anak selama bersekolah. Orangtua menjadi pembimbing rohani anak karena belum memiliki mentor atau pembimbing rohani di lingkungan gerejanya.

Dalam hal belajar anak Deo (Responden 9) tidak pernah melanggar jadwal dalam mengerjakan tugas, karena belajar menjadi prioritas utama yang menjadi disiplin orangtua bagi anak, konsentrasi belajar anak akan terganggu pada saat tidak focus dalam mengerjakan tugas sekolah. Anak tidak pernah mengalami gangguan pada mata nya seperti padangan kabur, atau juga seperti kepala melayang atau leher bagian belakang yang sakit. Kejadian Kekurangan tidur akibat bermain smartphone tidak pernah dialami Deo. Anak kadang menolak ajakan orangtua untuk keluar berbareng dalam waktu keluarga. Sementara kesengajaan dalam pengabaian pengerjaan tugas sekolah, tidak pernah terjadi. Ketergantungan mutlak pada smartphone tidak terdapat pada anak Deo yang tidak pernah mengalami hal bermain smartphone pada saat tidurnya. Perilaku anak biasa lebih banyak bicara yang diperlihatkan pada saat tidak mampu mengontrol diri dalam keinginan menggunakan smartphone. Anak tidak pernah menunjukan masalah apabila tidak menggunakan smartphone, begitu juga dengan penarikan diri atau lainnya. Anak cukup bertanggung jawab, sehingga hal - hal yang tidak diinginkan berupa berbohong tidak mengerjakan tugas sekolah hanya karena keinginan bermain smartphone pun tidak pernah terjadi.

\section{KESIMPULAN}

Pengaruh Pendidikan Agama Kristen pertama berdampak kepada guru pengajar yang lebih ditekankan bukan hanya sebagai pendidik tetapi juga menjadi orang tua kedua yang memiliki tanggung jawab dalam hal perkembangan kerohanian anak didik. Orangtua memiliki kepercayaan pada Sekolah Kristen dalam memutuskan dan menetapkan untuk menyekolahkan anak demi masa depan mereka, dimana kebanyakan adalah orangtua yang bukan dari agama Kristen. 
Perubahan perilaku anak menjadi lebih baik yang dirasakan serta dialami orangtua di rumah, setelah bersekolah dan mendapat bimbingan terus menerus dari guru. Orangtua percaya dengan pengajaran nilai - nilai kristiani dapat mengubah pola hidup anak menjadi lebih bertanggung jawab dan percaya diri.

Ketergantungan smartphone pada anak dapat diatasi dan di cegah sebelum terjadi dengan menguatkan kerohanian anak. Kerjasama orangtua dan guru dengan terus membangun komunikasi yang baik serta penerapan kegiatan sosial ke kristenan membantu anak untuk mempunyai kegiatan positif lainnya, dan menghilangkan obsesi anak pada smartphone. Melalui Pendidikan Agama Kristen yang terus mengajari anak agar berpusat pada Kristus menjadi benteng awal yang baik sebagai cara preventif keterikatan anak pada smartphone.

Tanggung jawab mementor anak atau menjadi contoh yang baik dan benar adalah berada pada orangtua masing - masing.

\section{KEPUSTAKAAN}

A., Hidayat A. A. Pengantar Kebutuhan Dasar Manusia: Aplikasi Konsep Dan Proses Keperawatan, Buku 2. Jakarta: Salemba Medika, 2009.

A.G., Potter P. A. \& Perry. "Buku Ajar Fundamental Keperawatan: Konsep, Proses Dan Praktik." Alih Bahasa Komalasari 2, no. 4 (2005): 4.

Hadi, Sutrisno. Methodology Research D. Yogyakarta: YPFP UGM, 1986.

Lahagu, Ardianto. "Peran Pendidikan Agama Kristen Dalam Membangun Karakter Remaja Di Sekolah Menengah Pertama.” Real Didache 2, no. 1 (2017): 105-129.

Wojowasito, S. Kamus Lengkap Inggris-Indonesia. Bandung: Hasta, 1980.

"Https:/Www.Liputan6.Com/News/Read/3230086/Kecanduan-Smartphone-2-Pelajar-DiBondowoso-Alami-Gangguan-Jiwa." 1 Oktober. "Https:/Www.Suara.Com/Health/2019/07/05/063500/Kecanduan-Ponsel-Bocah-Ini-IdapGangguan- Kesehatan-Mental." 1 Oktober. 